\title{
Distribution of shallow water soft and hard bottom seabeds in the Isla del Coco National Park, Pacific Costa Rica
}

\author{
Jeffrey A. Sibaja-Cordero ${ }^{1,2,3 *}$, Jesús S. Troncoso ${ }^{1}$, Catalina Benavides-Varela ${ }^{2,3}$ \\ \& Jorge Cortés ${ }^{2,3}$ \\ 1. Departamento de Ecología y Biología Animal, Facultad de Ciencias del Mar, Universidad de Vigo, Campus Lagoas \\ Marcosende, 36310 Vigo, Spain \\ 2. Centro de Investigación en Ciencias del Mar y Limnología (CIMAR), Universidad de Costa Rica, San Pedro, 11501- \\ 2060 San José, Costa Rica \\ 3. Escuela de Biología, Universidad de Costa Rica, San Pedro, 11501-2060 San José, Costa Rica. \\ * Corresponding author. E-mail address: jeffro@costarricense.cr (J.A. Sibaja-Cordero).
}

Received 17-II-2012. C Corrected 16-VII-2012. Accepted 24-IX-2012.

\begin{abstract}
Geographic Information Systems (GIS) applications used in marine habitats are powerful tools for management and monitoring of marine reserves and resources. Here, we present a series of maps of the soft and hard substrates in the shallow waters $(>80 \mathrm{~m}$ depth) of Parque Nacional Isla del Coco (PNIC $=$ Isla del Coco National Park). We use bathymetry data and field data as input for a GIS, GAM, and kriging methods to generate a series of maps that describe the bottom characteristics. Eight types of bottom were found in the PNIC by composition and grain size. The shore of the island and islets consisted of rocky formations (mainly basalts), with coral reefs in the subtidal of some areas. Rhodolith beds had a dispersing distribution. The bottom on the southern and southwestern region is hard substrate, while sediments cover the northern and northeastern zones. Slightly gravelly sand dominated the bays, while gravelly sand (with more coarse grains) was frequent offshore. The inner areas of Chatham and Wafer bays have mud and organic matter. The sediments in the area are mostly carbonates, except in Bahía Yglesias where clastic sediments (from the erosion of basalts) are presented. The information generated in this study could be a valuable input for future monitoring in the PNIC. Citation: Sibaja-Cordero, J.A., J.S. Troncoso, C. Benavides-Varela \& J. Cortés. 2012. Shallow water soft and hard bottoms of Isla del Coco National Park, Pacific Costa Rica. Rev. Biol. Trop. 60 (Suppl. 3): 53-66. Epub 2012 Dec 01.
\end{abstract}

Key words: GIS, Isla del Coco, Costa Rica, maps, sand bottom, carbonates, reefs, shallow water systems, substrate, costal management, sediments.

Geographic Information Systems (GIS) applications to marine habitats are a powerful management and monitoring tools for marine protected areas and resources (Fonseca et al. 2010). For example, Levinson (2008) used GIS to map of coral reefs around Rossel Island, Papua New Guinea: and took the autochthonous language to relate these names with the marine resource utilization by local people. Guzman et al. (2008) and Mair et al. (2009) mapped using GIS the sediments, bathymetry, benthos, and coral reefs in the Las Perlas Archipelago in Panamá. These studies sustain the establishment of the boundaries of a marine protect area around the Archipelago.

The importance of map marine habitats was showed by the study of Fonseca et al. (2010) that presented the distribution of marine habitats in the marine protected area, Reserva Biológica Isla del Caño, located on the southern Pacific coast of Costa Rica. They used other techniques with supervised classification 
of high resolution images validated with field data, and they provided management recommendations based in their results.

Beaman (2005) made a characterization of the benthic habitats in various regions of Australia using geostatistical applications for mapping the substrates. Also, they include under water video and image analysis. Beaman (2005) show also that sediment fractions vary spatially.

The implementation of GIS is required in Parque Nacional Isla del Coco (PNIC) because the island is highly visited by divers, ecologists and scientists. Also, having the information of the area in a GIS is crucial because it is a World Heritage Site with high biodiversity, especially of marine life and coral reefs. The knowledge of the configuration and composition of the marine bottom is scarce. Lizano (2001a) generated a bathymetric map of the platform around the island, using the ecosounder of the $\mathrm{R} / \mathrm{V}$ Searcher of the University from Costa Rica, a nautical chart, and a GPS with precision of \pm 20m, in June 1994. Garrison (1995) presented a GIS map with the locations of the main coral reefs around the island and islets. Isla del Coco is an information gap of rock and soft bottom characteristics. Previous information (TNC 2008), use for management decisions of the area are made with theoric models, and results are coarse and in the shallow waters only reported hard substrates.

The present study generated a series of GIS maps of the sediment and bottom types (categories of substrate) in shallow waters around Isla del Coco. The layers of the Instituto Geográfico Nacional de Costa Rica (IGNCR) and the isobaths of Lizano (2001a, b) were used as the base for this study. The main goal of the present study is create a Geographic Information System for using in the management of scientific and touristic activities.

\section{MATERIAL AND METHODS}

Study site: Parque Nacional Isla del Coco

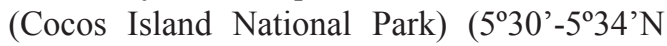
and $87^{\circ} 01^{\prime}-87^{\circ} 06^{\prime} \mathrm{W}$ ) is an oceanic island in the Eastern Tropical Pacific (Fig. 1), located about $500 \mathrm{~km}$ off the Pacific coast of Costa Rica and more than $600 \mathrm{~km}$ from Galápagos Islands and Malpelo Island (Lizano 2001a). The island measures $4.4 \times 7.6 \mathrm{~km}$, with an area of $24 \mathrm{~km}^{2}$, and the maximum height is $575.5 \mathrm{~m}$ at Cerro Yglesias. The cliffs and boulder beaches consist of basalts and have different wave exposure; the tidal range is $\sim 4 \mathrm{~m}$. The protected marine ecosystems account for $1997 \mathrm{~km}^{2}$ (Weston 1992, Lizano 2001a, Sibaja-Cordero 2008). The island began as part of the submarine volcanic bell (Cocos Ridge) at the Galápagos Hotspot and finished its configuration with subaerial eruptions (Alvarado-Induni 2000), such as the ignimbrite blocks in Bahía Wafer (Sibaja-Cordero \& Cortés 2010). The Cocos Island is the only emerged point of the Cocos Ridge (Castillo et al. 1988, Lizano 2001a).

The platform around the island is about $18 \mathrm{~km}$ long and extends in a southwest-northeast direction with borders at about $180 \mathrm{~m}$ depth. Below this depth, the rocky walls are steep down to the crest of the range at about of $2000 \mathrm{~m}$ depth. The slope continues to the base of the ridge at 3000m depth (Lizano 2001a). The GIS data show that the bottom is hard, from intertidal to 35 or $55 \mathrm{~m}$, in the southsouthwest and north-northeast, respectively. Below this zone, the platforms show a gradient from bioclastic to clastic muds (Fig. 2).

Sample collection: Isla del Coco was visited during the UCR-UNA-COCO-I Expedition aboard the MV Argo from 19 to 29 April 2010. The sampling was carried out in 46 stations around the island, and sites were selected represented depth and wave exposure gradients within places. In stations 1 to 27 (Table 1, Fig. 1 ), the bottom was composed by sediments, for this reason the samples were taken with a van Veen dredge with a $25 \times 25 \mathrm{~cm}$ sampling area, between 3 and 80 meters deep at low tide. While the other 19 stations were hard substrates, according with field inspection of substrate (stations A-R in Table 1, Fig. 1).

In the laboratory, the sediments of each station were dried (three days at $60^{\circ} \mathrm{C}$ ), and 


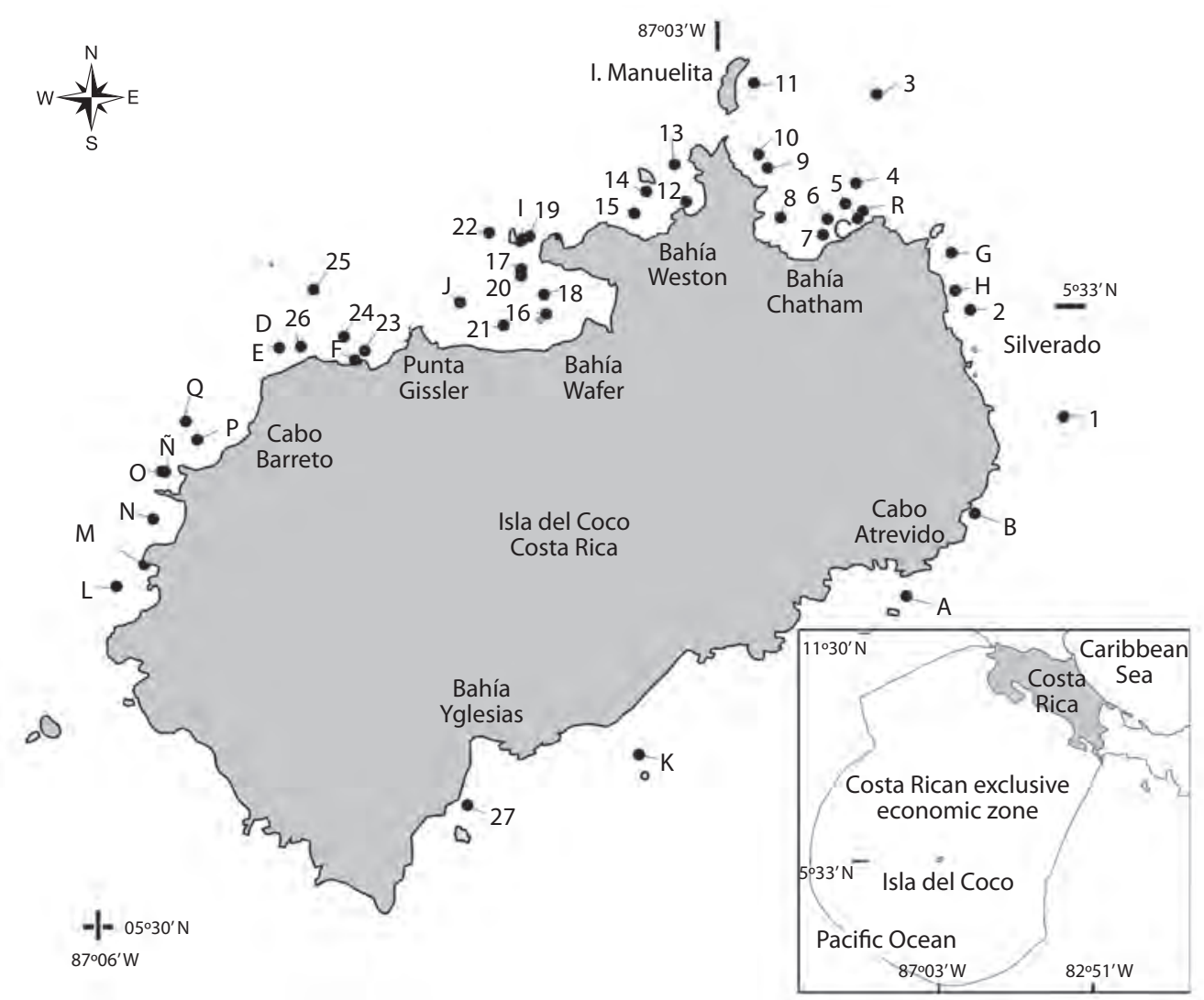

Fig. 1. Sampling of soft bottom (1-27) and hard bottom (A-R), around Parque Nacional Isla del Coco, Costa Rica.

a digital photograph was taken without flash of a subsample of $10 \mathrm{~g}$ in a crucible at the same hour of the day to reduce to reduce light intensity variation. The color of sediment was numerically measured as the mean pixel value in gray scale of the image of each sample in the UHTSCSA Image Tool software with the histogram command. The pixels were represented as 8-bit unsigned integers, ranging in value from 0 to 255 . In the gray scale palette, a pixel value of 0 is displayed as black and 255 as white, so dark sediments had low values while the white sands had high values.

A subsample of sediment $(250 \mathrm{~g})$ was taken from each dredge for grain size analyses, determination of the percentage of organic matter (by weight loss with the ignition method) and percentage of carbonates (by back titration method) (Ryan et al. 2001, Eleftheriou \& McIntyre 2005).

Description of Available GIS data: First, a review of the preexisting geographic information of Isla del Coco was made., This information includes the coastline of the island, rivers, contour lines and reefs (IGNCR 2002, ITCR 2008), types of bottom (TNC 2008), bathymetry (Lizano 2001b, TNC 2008), and a non-georeferenced map of the island (SINAC 1999), with the approximate location of reefs and cliffs. Then, all the Geographic information was compiled in GIS (shape file) format.

Geographic Information processing: The layers presented different coordinate systems: Costa Rica Transverse Mercator (CRTM05), 
TABLE 1

Stations for the study of bottom types and their latitude, longitude, and depth at chart datum $(0 \mathrm{~m})$. Isla del Coco National Park, Costa Rica

\begin{tabular}{|c|c|c|c|c|}
\hline Place name & Station & N Latitude & W Longitude & Depth (m) \\
\hline El Arco & 1 & $5^{\circ} 32^{\prime} 11.0^{\prime \prime}$ & $87^{\circ} 01^{\prime} 22.5^{\prime \prime}$ & 60.1 \\
\hline Silverado & 2 & $5^{\circ} 32^{\prime} 40.2^{\prime \prime}$ & $87^{\circ} 01^{\prime} 47.7^{\prime \prime}$ & 9.7 \\
\hline Chatham & 3 & $5^{\circ} 33^{\prime} 39.4^{\prime \prime}$ & $87^{\circ} 02^{\prime} 13.0^{\prime \prime}$ & 74.8 \\
\hline Chatham & 4 & $5^{\circ} 33^{\prime} 15.0^{\prime \prime}$ & $87^{\circ} 02^{\prime} 18.6^{\prime \prime}$ & 34.8 \\
\hline Chatham & 5 & $5^{\circ} 33^{\prime} 09.3^{\prime \prime}$ & $87^{\circ} 02^{\prime} 21.6^{\prime \prime}$ & 16.0 \\
\hline Chatham & 6 & $5^{\circ} 33^{\prime} 05.2^{\prime \prime}$ & $87^{\circ} 02^{\prime} 26.4^{\prime \prime}$ & 8.5 \\
\hline Chatham & 7 & $5^{\circ} 33^{\prime} 00.8^{\prime \prime}$ & $87^{\circ} 02^{\prime} 27.6^{\prime \prime}$ & 4.6 \\
\hline Chatham & 8 & $5^{\circ} 33^{\prime} 05.6^{\prime \prime}$ & $87^{\circ} 02^{\prime} 39.1^{\prime \prime}$ & 2.6 \\
\hline Chatham & 9 & $5^{\circ} 33^{\prime} 19.2^{\prime \prime}$ & $87^{\circ} 02^{\prime} 42.6^{\prime \prime}$ & 10.0 \\
\hline Chatham & 10 & $5^{\circ} 33^{\prime} 22.9^{\prime \prime}$ & $87^{\circ} 02^{\prime} 45^{\prime \prime}$ & 10.5 \\
\hline Chatham & 11 & $5^{\circ} 33^{\prime} 42.6^{\prime \prime}$ & $87^{\circ} 02^{\prime} 46.2^{\prime \prime}$ & 15.0 \\
\hline Weston & 12 & $5^{\circ} 33^{\prime} 09.9^{\prime \prime}$ & $87^{\circ} 03^{\prime} 04.6^{\prime \prime}$ & 9.9 \\
\hline Weston & 13 & $5^{\circ} 33^{\prime} 20.2^{\prime \prime}$ & 8703'07.7' & 42.1 \\
\hline Weston & 14 & $5^{\circ} 33^{\prime} 12.7^{\prime \prime}$ & $87^{\circ} 03^{\prime} 15.4^{\prime \prime}$ & 18.5 \\
\hline Weston & 15 & $5^{\circ} 33^{\prime} 06.7^{\prime \prime}$ & $87^{\circ} 03^{\prime} 18.6^{\prime \prime}$ & 12.2 \\
\hline Wafer & 16 & $5^{\circ} 32^{\prime} 39.1^{\prime \prime}$ & $87^{\circ} 03^{\prime} 42.6^{\prime \prime}$ & 3.5 \\
\hline Wafer & 17 & $5^{\circ} 32^{\prime} 51.5^{\prime \prime}$ & $87^{\circ} 03^{\prime} 49.2^{\prime \prime}$ & 23.0 \\
\hline Wafer & 18 & $5^{\circ} 32^{\prime} 44.4^{\prime \prime}$ & $87^{\circ} 03^{\prime} 43.0^{\prime \prime}$ & 7.8 \\
\hline Wafer & 19 & $5^{\circ} 33^{\prime} 00.4^{\prime \prime}$ & $87^{\circ} 03^{\prime} 46.9^{\prime \prime}$ & 24.2 \\
\hline Wafer & 20 & $5^{\circ} 32^{\prime} 49.7^{\prime \prime}$ & $87^{\circ} 03^{\prime} 49.2^{\prime \prime}$ & 39.8 \\
\hline Wafer & 21 & $5^{\circ} 32^{\prime} 36.1^{\prime \prime}$ & $87^{\circ} 03^{\prime} 54.0^{\prime \prime}$ & 7.2 \\
\hline Wafer & 22 & $5^{\circ} 33^{\prime} 01.3^{\prime \prime}$ & $87^{\circ} 03^{\prime} 58.0^{\prime \prime}$ & 71.0 \\
\hline Gissler & 23 & $5^{\circ} 32^{\prime} 29.0^{\prime \prime}$ & $87^{\circ} 04^{\prime} 31.7^{\prime \prime}$ & 11.1 \\
\hline Gissler & 24 & $5^{\circ} 32^{\prime} 32.9^{\prime \prime}$ & $87^{\circ} 04^{\prime} 37.1^{\prime \prime}$ & 15.8 \\
\hline Gissler & 25 & $5^{\circ} 32^{\prime} 45.9^{\prime \prime}$ & $87^{\circ} 04^{\prime} 45.5^{\prime \prime}$ & 53.2 \\
\hline Gissler & 26 & $5^{\circ} 32^{\prime} 30.2^{\prime \prime}$ & $87^{\circ} 04^{\prime} 48.9^{\prime \prime}$ & 12.6 \\
\hline Yglesias & 27 & $5^{\circ} 30^{\prime} 24.4^{\prime \prime}$ & $87^{\circ} 04^{\prime} 03.8^{\prime \prime}$ & 12.5 \\
\hline Cabo Atrevido & A & $5^{\circ} 31^{\prime} 21.8^{\prime \prime}$ & $87^{\circ} 02^{\prime} 05.1^{\prime \prime}$ & 34.0 \\
\hline Cabo Atrevido & B & $5^{\circ} 31^{\prime} 44.4^{\prime \prime}$ & $87^{\circ} 01^{\prime} 46.5^{\prime \prime}$ & 15.0 \\
\hline Chatham & $\mathrm{C}$ & $5^{\circ} 33^{\prime} 05.3^{\prime \prime}$ & $87^{\circ} 02^{\prime} 18.3^{\prime \prime}$ & 15.0 \\
\hline Gissler & $\mathrm{D}$ & $5^{\circ} 32^{\prime} 29.9^{\prime \prime}$ & $87^{\circ} 04^{\prime} 54.7^{\prime \prime}$ & 19.8 \\
\hline Gissler & $\mathrm{E}$ & $5^{\circ} 32^{\prime} 29.9^{\prime \prime}$ & $87^{\circ} 04^{\prime} 54.7^{\prime \prime}$ & 25.9 \\
\hline Gissler & $\mathrm{F}$ & $5^{\circ} 32^{\prime} 26.4^{\prime \prime}$ & $87^{\circ} 04^{\prime} 34.2^{\prime \prime}$ & 21.9 \\
\hline Punta Ulloa & G & $5^{\circ} 32^{\prime} 55.9^{\prime \prime}$ & $87^{\circ} 01^{\prime} 52.8^{\prime \prime}$ & 10.4 \\
\hline Punta Ulloa & $\mathrm{H}$ & $5^{\circ} 32^{\prime} 45.6^{\prime \prime}$ & $87^{\circ} 01^{\prime} 51.9^{\prime \prime}$ & 9.8 \\
\hline Wafer & I & $5^{\circ} 32^{\prime} 59.7^{\prime \prime}$ & $87^{\circ} 03^{\prime} 48.9^{\prime \prime}$ & 20.7 \\
\hline Wafer & $\mathrm{J}$ & $5^{\circ} 32^{\prime} 42.4^{\prime \prime}$ & $87^{\circ} 04^{\prime} 05.8^{\prime \prime}$ & 11.1 \\
\hline Yglesias & $\mathrm{K}$ & $5^{\circ} 30^{\prime} 38.3^{\prime \prime}$ & $87^{\circ} 03^{\prime} 17.4^{\prime \prime}$ & 27.0 \\
\hline Cabo Lionel & $\mathrm{L}$ & $5^{\circ} 31^{\prime} 24.3^{\prime \prime}$ & $87^{\circ} 05^{\prime} 38.8^{\prime \prime}$ & 33.2 \\
\hline Cabo Lionel & M & $5^{\circ} 31^{\prime} 30.4 "$ & $87^{\circ} 05^{\prime} 31.2^{\prime \prime}$ & 10.1 \\
\hline Punta María & $\mathrm{N}$ & $5^{\circ} 31^{\prime} 42.9^{\prime \prime}$ & $87^{\circ} 05^{\prime} 28.9^{\prime \prime}$ & 11.1 \\
\hline Punta María & $\tilde{\mathrm{N}}$ & $5^{\circ} 31^{\prime} 55.7^{\prime \prime}$ & $87^{\circ} 05^{\prime} 25.5^{\prime \prime}$ & 24.7 \\
\hline Punta María & $\mathrm{O}$ & $5^{\circ} 31^{\prime} 55.9^{\prime \prime}$ & $87^{\circ} 05^{\prime} 26.5^{\prime \prime}$ & 61.0 \\
\hline Cabo Barreto & $\mathrm{P}$ & $5^{\circ} 32^{\prime} 04.6^{\prime \prime}$ & $87^{\circ} 05^{\prime} 16.8^{\prime \prime}$ & 10.1 \\
\hline Cabo Barreto & Q & $5^{\circ} 32^{\prime} 09.6^{\prime \prime}$ & $87^{\circ} 05^{\prime} 20.0^{\prime \prime}$ & 10.1 \\
\hline Chatham & $\mathrm{R}$ & $5^{\circ} 33^{\prime} 07.5^{\prime \prime}$ & $87^{\circ} 02^{\prime} 16.8^{\prime \prime}$ & 15.0 \\
\hline
\end{tabular}




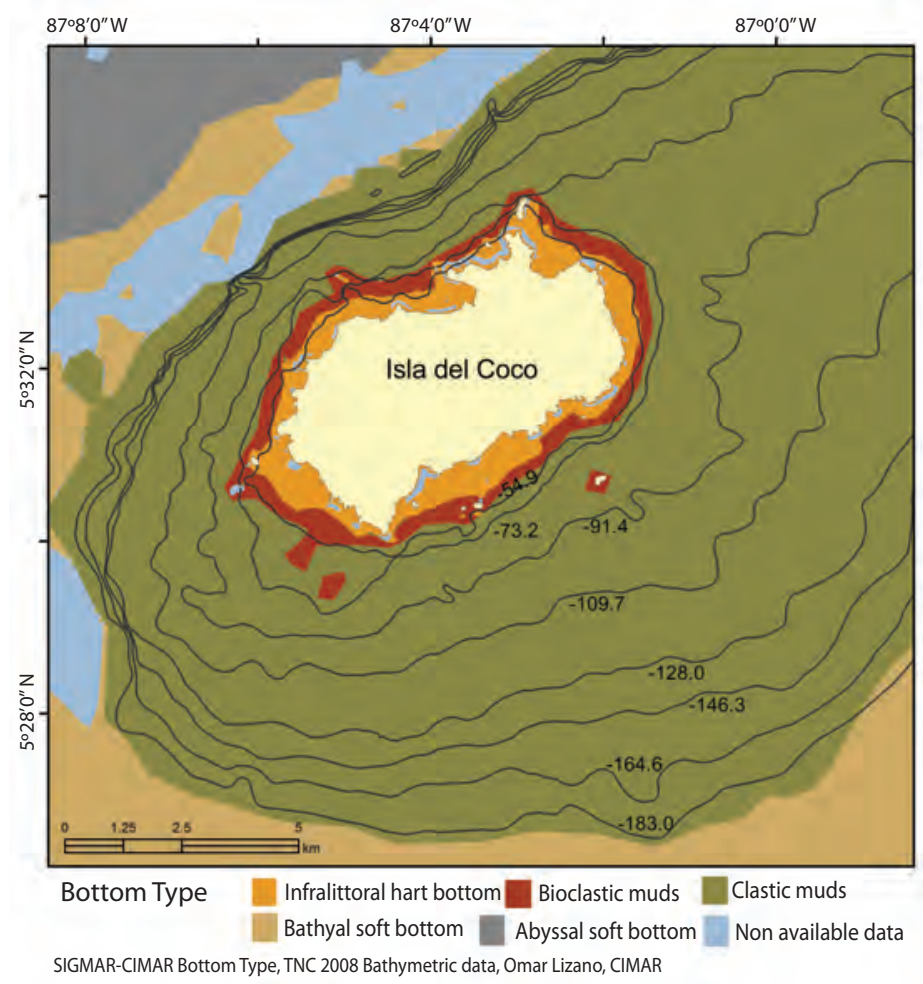

Fig. 2. Map of bottom types, based on the study by TNC (2008) and bathymetric isobaths, based on Lizano (2001) of the platforms of Isla del Coco.

Universal Transverse Mercator UTM Zone 27, NAD 16N_NAD 83) and coordinates (Lat/ Long-WGS84), and it was necessary to transform them to the same system (Lat/LongWGS84) for their evaluation. This process was done using as basis the official maps of the National Geographic Institute of Costa Rica (IGNCR 2002)

Bathymetric model: A point layer was created using the depth data provided by Lizano (2001b), and generated an isobaths layer, with the Xtools extension for ArcView 3.3 and was adjusted to the official cartography of IGNCR (IGNCR 2002). Then, the data were projected to the CRTM05 coordinate system and the bathymetric model was generated using the 3D Analyst extension for ArcGIS10 (ESRI 2010). The bottom type, grain size, and substrate type layers were generated from field data, described previously. The digital elevation model was generated from contour lines of IGNCR (2002) layers.

Statistical analysis: Generalized additive models (GAM) were used to determinate the relationship of the geographic position (as an isotropic smooth) and the depth (linear term) with the sediment characteristics. The model was implemented on the mgcv package for $\mathrm{R}$ (Wood 2006). The GAMs were carried out with a log link with Gamma error structure (Crawley 2007). A full model (geographic position and depth) was tested against a model without the depth using ANOVA. The deviance explained (DE) of the models was compared. The formula of the full model was:

$$
\mathrm{Y} \sim \mathrm{s}(\text { Longitude, Latitude, } \mathrm{k}=25)+\text { depth }
$$

where $\mathrm{Y}=$ sediment characteristic, $\mathrm{s}=$ smooth regressor, and $\mathrm{k}$ is the dimension of the basis 
used to represent the smooth term. The models have $\mathrm{n}=27$.

The smooth of location was plotted on a map. Also, a gridding (spatial interpolation) was generated in the software PAST using the kriging algorithm with the default semivariogram (spherical with 10 bins) to create a color map of each sediment variable. The semivariograms generated fulfilled the assumption of 30 distances between points in the majority of bins (Hammer et al. 2001).

With the GRADISTAT software (Blott $\&$ Pye, 2001), the mean of grain size of each sample was calculated, and the software provides discrimination of samples based in their sedimentary data by bottom types (sediment name). The hard bottom was named also as bottom types according with the substrate: coral, rhodoliths or rock.

\section{RESULTS}

Eight types of bottom substrates were found during the sampling (Fig. 3). Coral reefs were represented around the island and islets. The basaltic rock was the most common

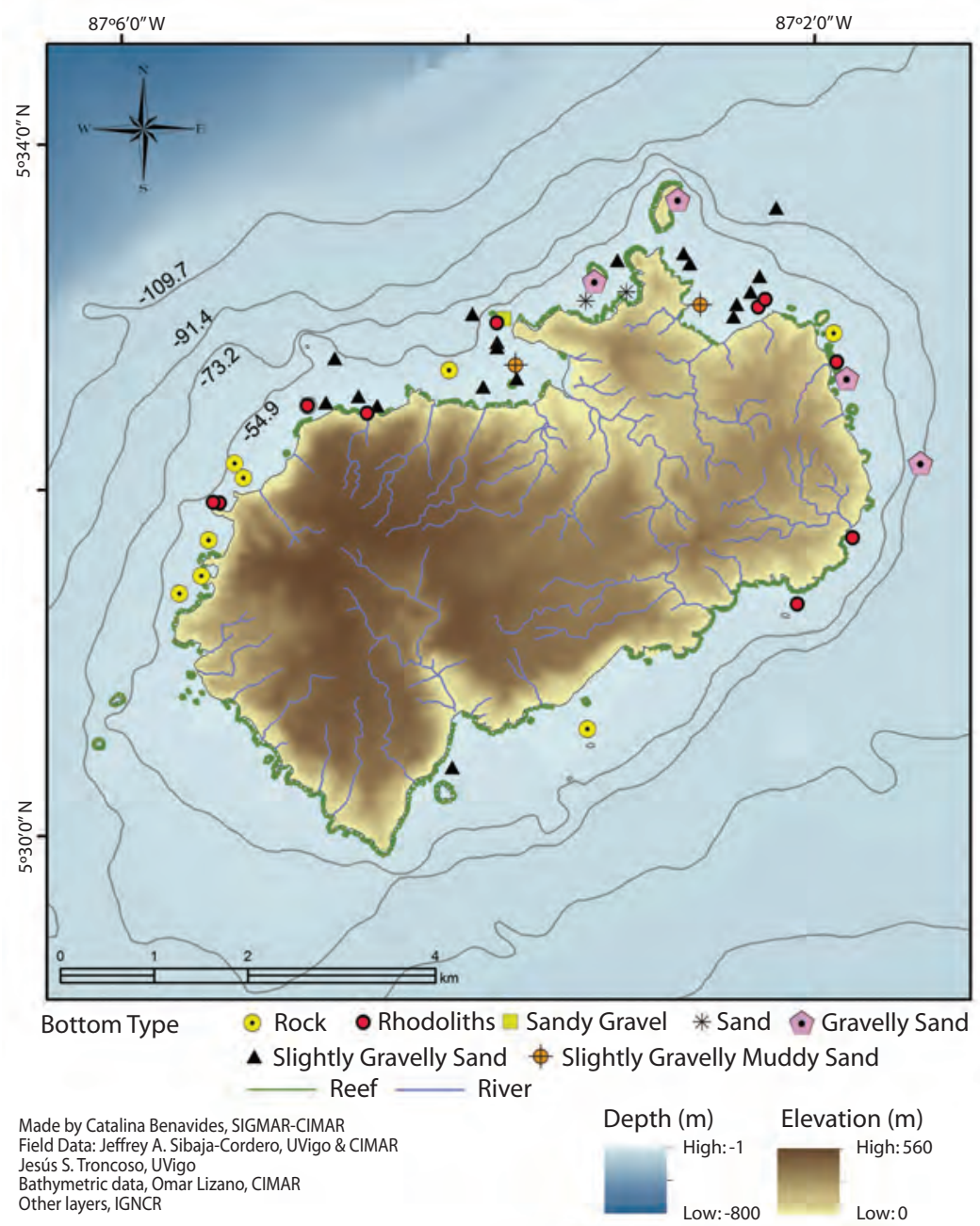

Fig. 3. Map of bottom types of the stations studied, also shows the bathymetry and the distribution of reefs, topography and rivers of Isla del Coco, Costa Rica (based on INGCR 2002). 
bottom type in the western and southwestern of the island. The rhodoliths were found at scattered points around the exposed sites of the island. Different types of sands were common in the east and northeast. The slightly gravelly sand was the most common sand type. Inner sections of Chatham and Wafer bays had mud inputs changing the grain size distribution.

In Wafer and Chatham bays, there are sand patches of diverse area within the coral and rocky reefs that surrounding the coast. The following results of granulometry and environmental variables are applicable to the zones and patches of sand in the island.
The sandy fraction was common in the northeast of the island (Fig. 4). Silt and clay were dominated fractions in the inner areas of Chatham and Wafer bays (Fig. 4). The gravel presented high percentage offshore of Weston and Chatham bays and in the eastern coast of the island.

The sediment fraction greater than $2000 \mu \mathrm{m}$ (Gravel) presented a tendency to increase with depth $(\mathrm{t}=-2.08, \mathrm{p}=0.058)$, and was correlated to geographic position $(\mathrm{F}=2.71, \mathrm{p}=0.038, \mathrm{DE}=$ $84.2 \%$ ), with the gravel increasing offshore (Fig. 5A). The kriging method shows that Bahía Weston and Silverado contained the

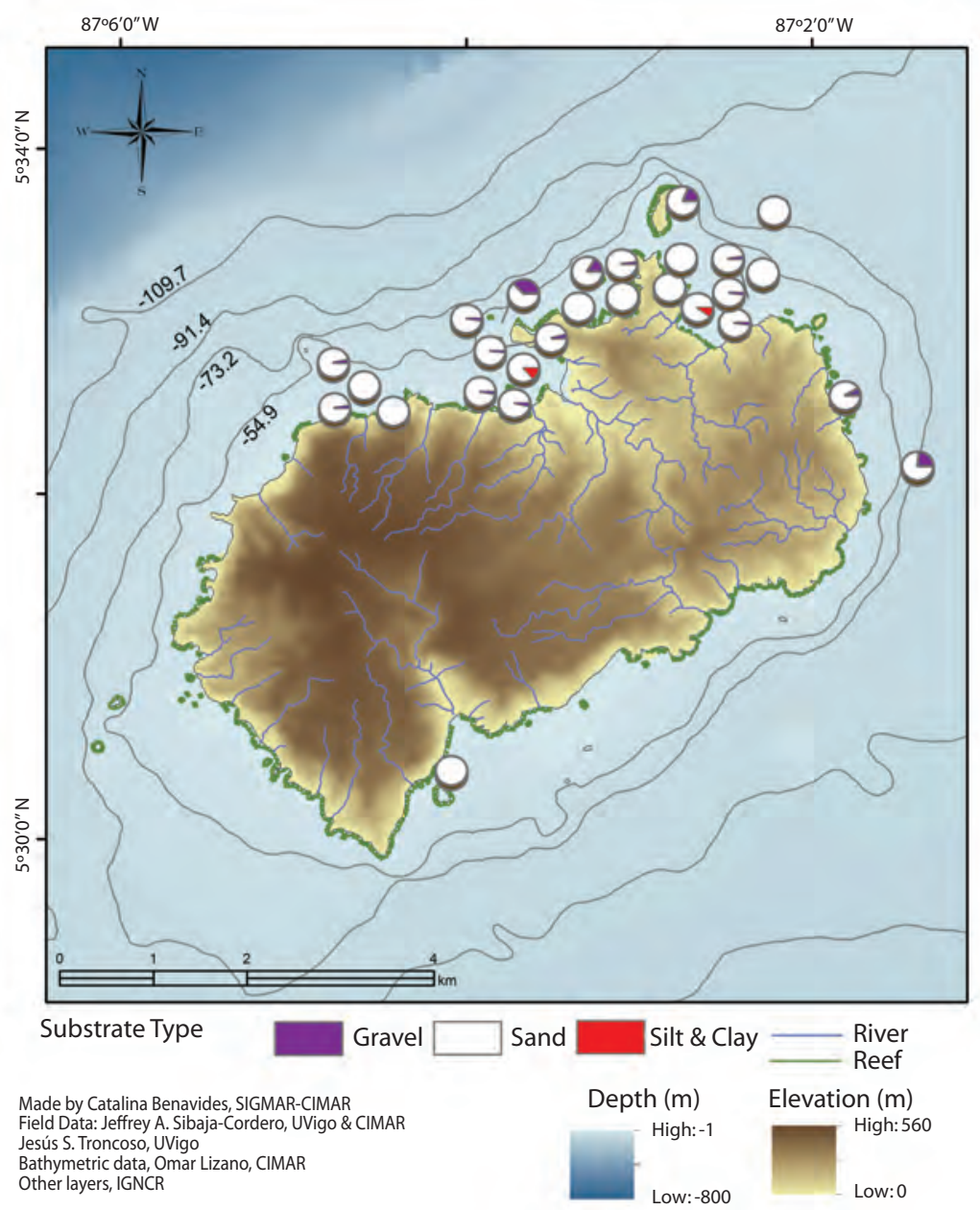

Fig. 4. Map of substrate types (Gravel, Sand and Silt-Clay fractions) for the stations studied. Isla del Coco, Costa Rica. 

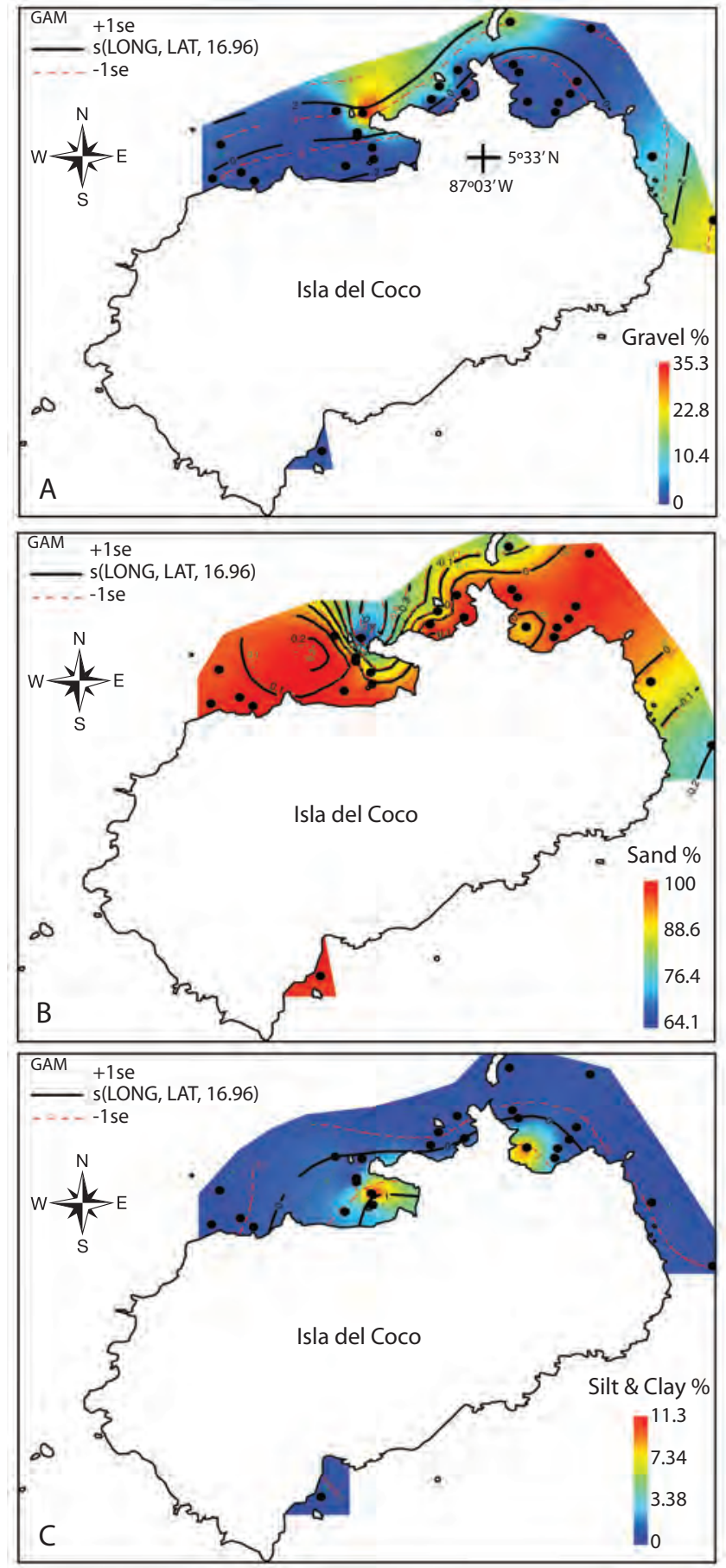

Fig. 5. Maps showing the GAM centered response on log scale (black continuous lines): A) Gravel, B) Sand, C) Silt and Clay. The standard error is shows as dashed lines, in green color positive error, and in red color negative error. The spatial interpolation by kriging algorithm shows each sediment variable in a color scale. Isla del Coco, Costa Rica. 
highest percent of gravel and the bays had the lowest (Fig. 5A). The percentage of the sand fraction was not related to depth $(\mathrm{t}=-0.54$, $\mathrm{p}=0.681$ ) and presented a complex geographic pattern $(\mathrm{F}=299.5, \mathrm{p}=0.042, \mathrm{DE}=100 \%)$, but the maximum and minimum were contrary to the gravel fraction (Fig. 5A, B). The kriging methods show the highest values of sand in the bays (Fig. 5B). The sand fraction in the present study include grain sizes less than 2000 but greater than $63 \mu \mathrm{m}$, and a GAM of each sediment fractions between those sizes indicated that grain fractions within $2000-350 \mu \mathrm{m}$ increased in percent offshore $(p<0.05)$, the fraction within the $350-250 \mu \mathrm{m}$ have no geographic pattern ( $>0.05)$, and the fractions less than $250 \mu \mathrm{m}$ increased near the shore $(\mathrm{p}<0.05)$. The silt and clay fraction $(<63 \mu \mathrm{m})$ increased near the shore $(\mathrm{F}=2.22, \mathrm{p}=0.0678, \mathrm{DE}==$ $74.6 \%$ ), without a linear relation with depth ( $>0.05$ ) (Fig. 5C). The pattern was of grain size increasing offshore of the bays $(\mathrm{F}=4.732$. $\mathrm{p}=0.003, \mathrm{DE}=87.4 \%$ ). The GIS map of grain size distribution supports this pattern (Fig. 7).

Based on IGNCR data the majority of rivers in the island are relatively short (Fig. 3), and finish in waterfalls, but in the bays of Yglesias, Chatham, and Wafer were the mouth of main rivers basin (Yglesias, Lièvre, and Genio respectively) with relatively large watersheds. The presence of these rivers in the bays was associated with the total organic matter (TOM). This variable was related to the geographic position $(\mathrm{F}=6.864, \mathrm{p}=0.003, \mathrm{DE}=93.8 \%)$, but the depth was not linearly related $(\mathrm{p}>0.05)$. The highest values were in the inner section of Bahía Chatham and Wafer, near the mouth of the rivers (Fig. 6A). The lowest value was in Bahía Yglesias. The pattern observed was, an increase in TOM values in the internal sections of the bays, and lower values on the island's west and south.

Carbonate concentrations were related to geographic position $(\mathrm{F}=13.05, \mathrm{p}<0.001, \mathrm{DE}=$ $77.2 \%$ ) but, depth is not a factor related with the amount of carbonates $(\mathrm{p}>0.05)$. Carbonates increased offshore, but the seabed presented lower values on the west and south of the island
(Fig. 6B). The color of the sediment was only related with the geographic position $(\mathrm{F}=14.06$, $\mathrm{p}<0.001, \mathrm{DE}=79.2 \%$ ), and the trend was a gradient of white sands to dark sediment from northeast to southwest (Fig. 6C).

\section{DISCUSSION}

Hard bottom: Dominance of hard substrates was found in the west and southwest of the island. Lizano (2001a) pointed out that the platform in this region had more bathymetric variation, and basaltic rocks reach the surface forming islets (Dos Amigos, Juan Bautista), and many submerged promontories. Some of these promontories are only exposed during the low tide (Lizano 2001a). The south side of the island has been explored, to $100 \mathrm{~m}$ depth and is remarkably different to the north side. Here, the platform is mostly rocky with low coral cover (Cortés \& Blum 2008). This characteristic resulted in a low content of carbonates in the sediment of Bahía Yglesias.

Fernández (2008) reported the presence of a rhodoliths beds in Isla del Coco, near Punta Ulloa. Moreover, we found that rhodoliths can be found in several places around the island; they have a dispersing distribution on the sand bottom and within rocks and coral reefs substrates. Specifically, we found them covered by several $\mathrm{cm}$ of sediment in the sandy areas of Bahía Weston. Hinojosa-Arango et al. (2009) mentioned the instability of the dispersed $v s$. clumped rhodoliths, and how sand layers in disturbed habitats can cover them. Due this, the rhodoliths substrates, can be subestimated if only visual techniques to determinate the bottom type were used.

Coral reef and isolated coral colonies were frequent in shallow waters of the Island and its islets. Fonseca et al. (2010) found a similar pattern in Isla del Caño, Costa Rica, where corals surrounded this island, but with lower development in the south region (Guzmán \& Cortés 1989).

Similarly, to Isla del Coco, Fonseca et al. (2010), found in Isla del Caño sections dominated by sand in the northeast and rocky bottom 

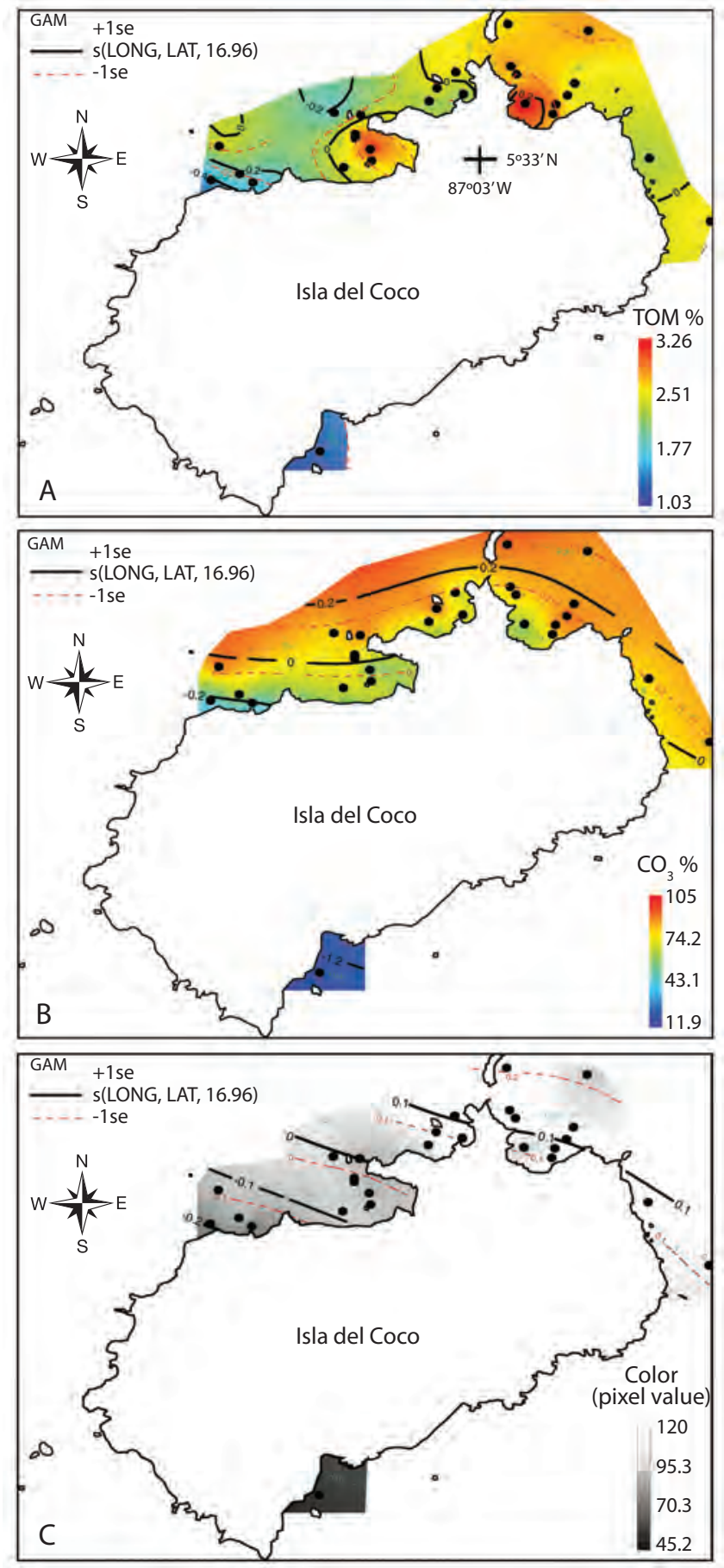

Fig. 6. Maps showing the GAM centered response on log scale (black continuous lines): A) TOM, B) $\mathrm{CO}_{3}$, and C) Color. The standard error is shows as dashed lines, in green color positive error, and in red color negative error. The spatial interpolation by kriging algorithm shows each sediment variable in a color scale. Isla del Coco, Costa Rica. 


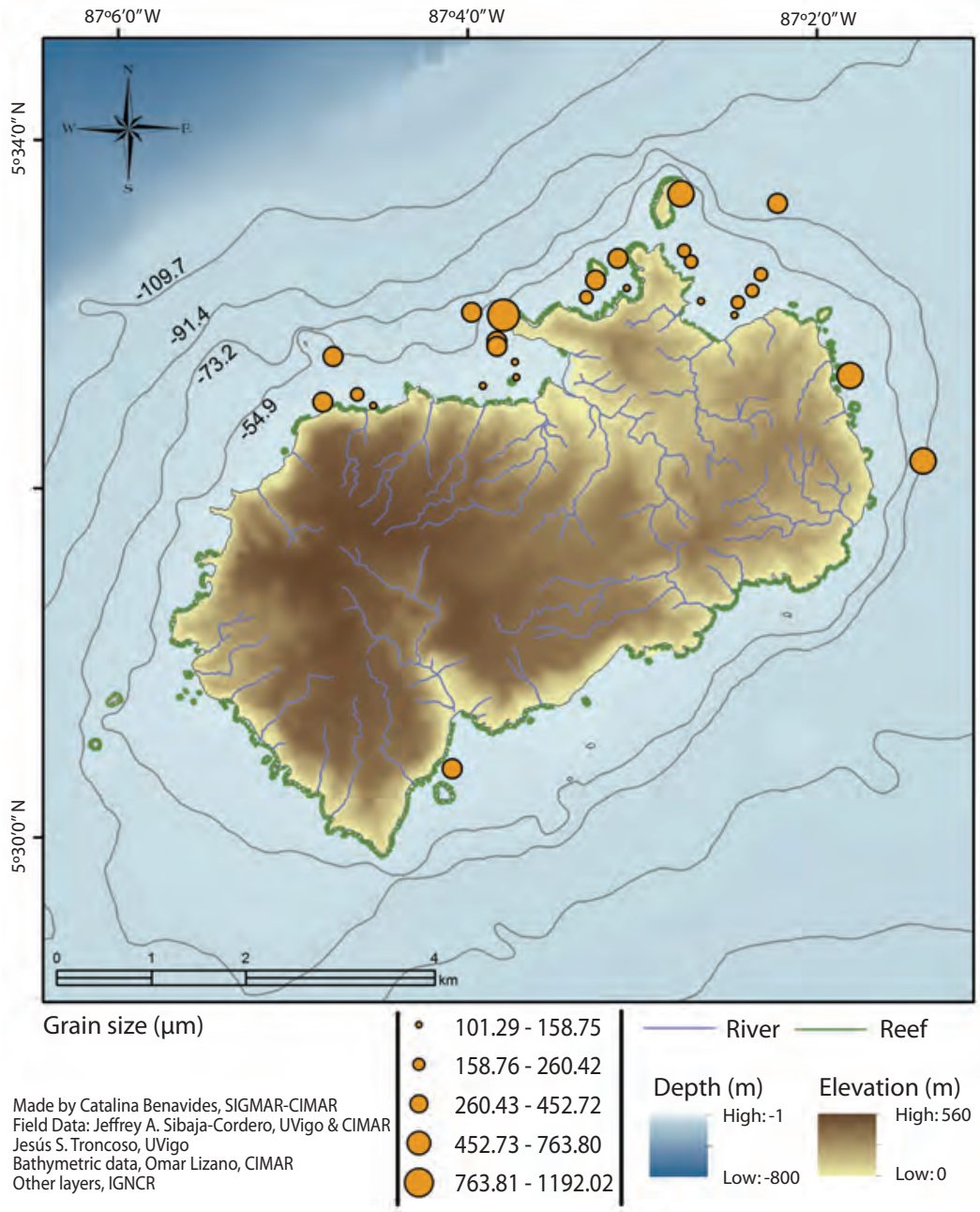

Fig. 7. Map indicating the predominant grain size at the stations studied. Isla del Coco, Costa Rica.

in the southwestern of the island. Waves and currents were frequent in the southern side of both islands and can determinate the distribution of sediments and corals (Guzmán \& Cortés 1989, 1992, Lizano 2008). Fonseca (2006) presented a map of Isla del Coco with eight coral reefs points. The map in Garrison (2005), with data of SINAC (1999), shows the borders of 17 coral formations, around the islets and near the shore. This last source of information cannot be used because discrepancies in the location of islets with the data of IGNCR (used in the presented study). Also, the IGNCR data did not discriminate between rocky and coral reefs (IGNCR 2002).

Soft bottom: The island has an extremely humid climate, with rainfalls during most part of the year (Alfaro 2008). The rivers Genio, Lièvre and Sucio drain into the inner sections of Wafer and Chatham bays, introducing mud and organic material to the coastal system. The slopes around these bays present some degree of deforestation product of use of wood by pirates, fishermen, and human colonies during the XIX century (Weston 1992). During 
the frequent rains, the soil is brought to the rivers and transported to the bays, especially the rivers on the west area of Chatham Bay: which come from a slope of shrub vegetation and produces the only mud beach of the island. The influence of mud in the sediments results, in fine material present in station 8 , as a sand patch within a coral reef (Fig. 1).

The geographic position was the main factor that determinates the characteristics of shallow sediments at Isla del Coco, and it concordance with the distance from the shore. The mean grain size tends to increase offshore. The coral reefs near the shore are the source of fine sediments from internal and external bioerosion (Guzmán \& Cortés 1992, 2007, Fonseca \& Cortés 1998, Alvarado \& Chiriboga 2008). The color of the sand is white in Bahía Weston, the west side of Bahía Chatham (Manuelita Channel), and it is dark (weathering of basalts) in Bahía Yglesias. The sediment color was due to high values of carbonates, and in some stations, other minerals contributed to light color of the sand, as iron impurities in the quartz crystals, contributed with yellow tones.

Ours data show how the bottom of the bays in less than $50 \mathrm{~m}$ presented sedimentary and hard bottom in contrasts with GIS data already available that only reports hard substrates (TNC 2008, Fig. 2).

Conclusions: This study incorporates the existing geographic data regarding the shallow water bottoms of Parque Nacional Isla del Coco. New information about sediment characteristics was added. Chatham and Wafer bays presented a gradient in their sedimentary characteristics; with finer grain size, lower carbonates concentrations and more organic matter in shallow water.

Each bottom type found represent a different habitat to the species that live in the waters of Isla del Coco. The Geographic Information System contains data of depth, organic matter, carbonates, percent of sand fractions, and bottom type. This GIS could be used in future studies, as well it should be taking into account in monitoring processes and definition activities regulation, in the island.

We found that some of the preexisting type- bottom information is not accurate; then, a most exhaustive study of the area covered by coral and bottom types is needed, especially on the southern area of the island.

\section{ACKNOWLEDGMENTS}

We thank the staff of CIMAR and the MV Argo crew (Undersea Hunter Group). José Vargas of CIMAR lent us the van Veen grab and mesh sieves. Thanks to Omar Lizano for permission to use the bathymetric data. This study was supported by CIMAR's Projects: "Descripción ambiental y de los organismos de los sedimentos marinos en el Parque Nacional Isla del Coco, Costa Rica", N808-B0-164, funded by the Vicerrectoría de Investigación, Universidad de Costa Rica, and "Interacciones oceáno-atmósfera y la biodiversidad marina de la Isla del Coco, Costa Rica.”, N808-B0-654, funded by the Consejo Nacional de Rectores de las Universidades Públicas de Costa Rica (CONARE). The trip of the second author to Isla del Coco was partially supported by INCITE Mobility Program of XUNTA de GALICIA (Spain) and ESF (European Social Fund). This manuscript is part of the doctoral dissertation of the first author at the University of Vigo, Spain.

\section{RESUMEN}

La aplicación de Sistemas de Información Geográfica (SIG), en los hábitats marinos es muy importante para la gestión y control de las reservas y recursos marinos. Aquí se presentan una serie de mapas de los sustratos sedimentarios y duros en las aguas poco profundas (> $80 \mathrm{~m}$ de profundidad) del Parque Nacional Isla del Coco (PNIC). Utilizamos datos de batimetría y datos de campo como entrada para un SIG, GAM, y los métodos de "kriging" para generar una serie de mapas que describen las características del fondo. Ocho tipos de fondo marino se encuentran en el PNIC. La orilla de la isla y los islotes consistía de formaciones rocosas (principalmente basaltos), con arrecifes de coral en el submareal de algunas áreas. Las camas de rodolitos tienen una distribución dispersa. El fondo al sur y suroeste es dominado por sustratos duros, 
mientras que en el norte y noreste, principalmente por los sustratos sedimentarios. La arena algo gravosa dominó en las bahías, mientras que la arena gravosa lo fue fuera de la costa. Sólo en dos puntos, las zonas interiores de las bahías de Chatham y Wafer, se tiene la presencia de barro y mayor materia orgánica. Los sedimentos fueron altos en contenido de carbonatos, principalmente de color claro, pero en Bahía Yglesias el sedimento era oscuro, por ser arena volcánica producto de la erosión de los basaltos. Los mapas elaborados a partir del presente estudio pueden ser utilizados para el seguimiento futuro de los recursos marinos en PNIC.

Palabras clave: SIG, Isla del Coco, Costa Rica, mapas, fondo de arena, carbonatos, arrecifes, sistemas de aguas poco profundas, sustrato, manejo costero, sedimentos.

\section{REFERENCES}

Alfaro, E.J. 2008. Ciclo diario y anual de variables troposféricas y oceánicas en la Isla del Coco. Rev. Biol. Trop. 56 (Suppl. 2): 19-29.

Alvarado, J.J. \& A. Chiriboga. 2008. Distribución y abundancia de equinodermos de las aguas someras en la Isla del Coco, Pacifico Oriental, Costa Rica. Rev. Biol. Trop. 56 (Suppl. 2): 99-111.

Alvarado-Induni, G.E. 2000. Volcanes de Costa Rica: Geología, historia y riqueza natural. EUNED, San José, Costa Rica.

Beaman, R. 2005. A GIS Study of Australia's Marine Benthic Habitats. PhD thesis, University of Tasmania.

Blott, S.J. \& K. Pye. 2001. GRADISTAT, A grain size distribution and statistics package for the analysis of unconsolidated sediments. Earth Surf. Proc. Land. 26: $1237-1248$.

Castillo, P., R. Batiza, D. Vanko, R.E. Malavassi, J. Barquero \& E. Fernández. 1988. Anomalously young and old hot-spot traces: I. Geology and petrology of Cocos Island. Bull. Geol. Soc. Amer. 100: 1400-1414.

Cortés, J. \& S. Blum. 2008. Life to $450 \mathrm{~m}$ depth at Isla del Coco, Costa Rica. Rev. Biol. Trop. 56 (Suppl. 2): 189-206.

Crawley, M.J. 2007. The R Book. John Wiley, New York.

Eleftheriou, A. \& A. McIntyre. 2005. Methods for the Study of Marine Benthos. Blackwell, Oxford.

ESRI. 2010. ArcGIS10 Software. Enviromental System Research Institute, Redlands, California, USA.

Fernández, C. 2008. Flora marina del Parque Nacional Isla del Coco, Costa Rica, Pacífico Tropical Oriental. Rev. Biol. Trop. 56 (Suppl. 2): 57-69.

Fonseca, A.C. 2006. Anexo 1, Atlas marino costero de Costa Rica: 209-219. In: V. Nielsen-Muñoz \& M.A. Quesada-Alpízar (Eds.). Ambientes Marino Costeros de Costa Rica. Comisión Interdisciplinaria Marino
Costera de la Zona Económica Exclusiva de Costa Rica, Informe Técnico. CIMAR, CI, TNC, San José, Costa Rica.

Fonseca, A.C. \& J. Cortés. 1998. Coral borers of the eastern Pacific: Aspidosiphon A. elegans (Sipuncula: Aspidosiphonidae) and Pomatogebia rugosa (Crustacea: Upogebiidae). Pac. Sci. 52: 170-175.

Fonseca, A.C., H.M. Guzmán, J. Cortés \& C. Soto. 2010. Marine habitats map of "Isla del Caño", Costa Rica, comparing Quickbird and Hymap images classification results. Rev. Biol. Trop. 58: 373-381.

Garrison, G. 2005. Peces de la Isla del Coco/Isla del Coco Fishes, 2nd ed. Edit. INBio, Heredia, Costa Rica.

Guzmán, H.M. \& J. Cortés. 1989. Coral reef community structure at Caño Island, Pacific Costa Rica. P.S.Z.N.I: Mar. Ecol. 10: 23-41.

Guzmán, H.M. \& J. Cortés. 1992. Cocos Island (Pacific of Costa Rica) coral reefs after the 1982-83 El Niño disturbance. Rev. Biol. Trop. 40: 309-324.

Guzman, H.M. \& J. Cortés. 2007. Reef recovery 20-yr after the 1982-83 El Niño massive mortality. Mar. Biol. 151: 401-411.

Guzman, H.M., S. Benfield, O. Breedy \& J.M. Mair. 2008. Broadening reef protection across the Marine Conservation Corridor of the Eastern Tropical Pacific: distribution and diversity of reefs in Las Perlas Archipelago, Panama. Environ. Conser. 35: 46-54.

Hammer, Ø., D.A.T. Harper \& P.D. Ryan 2001. PAST, Paleontological Statistics Software Package for Education and Data Analysis. Palaeontol. Electr. 4: 1-9.

Hinojosa-Arango, G, C.A. Maggs \& M.P. Johnson. 2009. Like a rolling stone: the mobility of maerl (Corallinaceae) and the neutrality of the associated assemblages. Ecology 90: 517-528.

IGNCR. 2002. Cocos Island Layers. Universal Transverse Mercator Projection (UTM), Zone 16N, NAD83 datum. Scale 1:25 000. Instituto Geográfico Nacional de Costa Rica, Ministerio de Obras Públicas y Transportes. San José, Costa Rica.

ITCR. 2008. Cocos Island Layers, Costa Rican Digital Atlas. Costa Rica Transverse Mercator Projection (CRTM05), datum WGS84. Scale 1:25 000. $3^{\mathrm{a}}$ ed. Instituto Tecnológico de Costa Rica. Cartago, Costa Rica.

Levinson, S.C. 2008. Landscape, seascape and the ontology of places on Rossel Island, Papua New Guinea. Language Scien. 30: 256-290.

Lizano, O.G. 2001a. Batimetría de la plataforma insular alrededor de la Isla del Coco, Costa Rica. Rev. Biol. Trop. 49 (Suppl. 2): 163-170.

Lizano, O.G. 2001b. Cocos Island bathymetric data. Geographical Coordinates. Centro de Investigación en 
Ciencias del Mar y Limnología (CIMAR), Universidad de Costa Rica. San José, Costa Rica.

Lizano, O.G. 2008. Dinámica de aguas alrededor de la Isla del Coco, Costa Rica. Rev. Biol. Trop. 56 (Suppl. 2): $31-48$.

Mair, J.M., S.L. Cunningham, J.A. Sibaja-Cordero, H.M. Guzman, M.F. Arroyo, D. Merino \& R. Vargas. 2009. Mapping benthic faunal communities in the shallow and deep sediments of Las Perlas Archipelago, Pacific Panama. Mar. Poll. Bull. 58: 375-383.

Ryan, J., G. Estefan \& A. Rashid. 2001. Soil and Plant Analysis Laboratory Manual. 2nd ed. International Center for Agricultural Research in the Dry Areas (ICARDA)-National Agricultural Research Center (NARC). Aleppo, Syria.

Sibaja-Cordero, J.A. 2008. Vertical zonation in the rocky intertidal at Cocos Island (Isla del Coco), Costa Rica: A comparation with other tropical locations. Rev. Biol. Trop. 56 (Suppl. 2): 171-187.
Sibaja-Cordero, J.A. \& J. Cortés. 2010. Comparación temporal de la composición y zonación de organismos en el intermareal rocoso del Parque Nacional Isla del Coco, Pacífico de Costa Rica. Rev. Biol. Trop. 58: 1387-1403.

SINAC. 1999. Cocos Island Marine Conservation Area. Sistema Nacional de Áreas de Conservación, Ministerio del Ambiente y Energía. San José, Costa Rica.

TNC. 2008. Bathymetric and benthic models. Assessment of Marine Ecoregions in Mesoamerica. Universal Transverse Mercator Proyection (UTM) Zone 16N, NAD27 datum. The Nature Conservancy, San José, Costa Rica.

Weston, J.C. 1992. La Isla del Coco / Cocos Island. Trejos Hermanos Sucesores, S.A., San José, Costa Rica.

Wood, S. 2006. Generalized Additive Models: An Introduction with R. Chapman and Hall/CRC, Boca Raton, Florida. 